\title{
It takes time to tango: The relative importance of values versus traits in consumer brand relationships
}

\author{
Ronald J.J. Voorn ${ }^{1,2}$ (D) । Gerrita van der Veen ${ }^{1}$ | Thomas J.L. van Rompay ${ }^{2}$ | Ad T.H. Pruyn ${ }^{2}$
}

${ }^{1}$ Department of Marketing, Market Research, and Innovation, University of Applied Sciences Utrecht, Utrecht, The Netherlands

${ }^{2}$ Faculty for Behavioural, Management and Social Sciences, University of Twente, Enschede, The Netherlands

Correspondence

Ronald J. J. Voorn, University of Twente, Enschede, $7522 \mathrm{NJ}$, The Netherlands. Email: ronald.voorn@utwente.nl

\begin{abstract}
Brand managers have several options in their quest to connect their brands with consumers. They may stress functional brand attributes and benefits, their brand's personality traits, or their brand's values (the human values attached to the brand). Which of these is most important to consumers is an open question, however. This article proposes that values may take on increased importance over time, as long-term relationships (in general) require more than just getting the job done (functional aspect) or a sense of recognition (trait correspondence). What is required most of all is a correspondence between long-term objectives and goals in life. Values are arguably the most relevant factor in longer relationships. An experiment was put together to determine if this is indeed the case. The results of our study suggest that values are indeed considered more important than traits in the case of longer relationships and that this is particularly true with decisions regarding prospective relationships and in the case of services.
\end{abstract}

\section{1 | INTRODUCTION}

Brand managers pursue different strategies in their quest to connect their brands to consumers and to maintain the brand's presence in the minds of these consumers. Finding the strategy that will be most successful in achieving these goals is almost like the quest for the Holy Grail (De Chernatony, 2009). The current study focuses on the benefits of using functional brand attributes, brand personality traits, or brand values (the human values a brand represents; Allen, 2002) as a starting point for building successful products or services. An experiment was conducted to investigate which of these is considered most important in relation to the length of time consumers used the products.

One of the first and oldest strategies used by managers is to stress functional brand attributes and the benefits these represent (e.g., Gutman, 1982; Rokeach, 1973). Second, they may position a brand as a personality with certain traits or behavioural characteristics (e.g., Aaker, 1997; Aguirre-Rodriguez, Bosnjak, \& Sirgy, 2012; Sirgy, Johar, Samli, \& Claiborne, 1991). Previous research showed that when brand personality traits ("the set of human personality traits that are both applicable to and relevant for brands," Azoulay \& Kapferer, 2003, pp. 151, as cited in Geuens, Weijters, \& de Wulf, 2009) or functional attributes align with the needs and desires of consumers, consumer responses such as brand preference and purchase decisions are more positive (Sirgy, Lee, \& Grace, 2016).

A third strategy involves the adoption of human values, which are very important life goals that guide the attitudes and actions of people across different situations (Schwartz, 2012). Adopting human values, and accentuating these values in the communication about the brand, is a strategy that has become increasingly popular in recent years (Hayman, 2017; Rodrigues Vila \& Bharadwaj, 2017). Brand values differ in comparison with brand personality traits, in so far as they reflect more stable and durable brand motivations and intentions-such as a concern for safety, the environment, or equality-whereas brand personality traits, as with human personality traits, are merely descriptions of a brand's personality traits and typical behaviour styles (Aaker, 1997; Geuens et al., 2008). In line with research testifying to the importance of consumer-brand congruence, previous studies showed that when the perceived value of a brand matches with those of consumers (i.e., when brands become part of consumers' extended selves; Belk, 1988), this might not only lead to better financial accomplishments (Jonsen, Galunic, Weeks, \& Braga, 2015) but also to attracting the right employees (Amos \& Weathington, 2008), stronger staff loyalty and helpfulness (Wang, Fu, Qiu, Moore, \& Wang, 2017), and better brand results (Alsem, Wieringa, \& Hendriks, 2007; Zhang \& Bloemer, 2008). 
This appears to be especially valid for services and products with which people have long-term relationships such as cars, laptops, banks, or insurance companies (Voorn, van der Veen, van Rompay, Hegner, \& Pruyn, 2016). As a matter of fact, some brands successfully use the length of the relationship in their advertising strategies, for example, "A bank for life" (German Nolthe and Lauth bank, 2017), "A Diamond is forever" by the De Beers company (Friedman, 2015), and "You never actually own a Patek Philippe. You merely look after it for the next generation" (Naas, 2016). A possible explanation as to why brands might benefit from this strategy can be found in ownership theory (e.g., Strahilevitz \& Loewenstein, 1998). This theory claims that objects become more valuable to owners the longer they have been in their possession. In other words, the longer someone possesses something, the more likely it is that the product becomes a candidate for the projection of values and desires (Gawronski, Bodenhausen, \& Becker, 2007; Ye \& Gawronski, 2016).

Although the latter may be an explanation for the importance of traits and values in retrospective relationships, it does not explain the relative importance of traits and/or values in prospective relationships. We would like to put forward another line of reasoning that holds that values may take on increased importance over time, as long-term relationships (in general) require more than just getting the job done (functional aspect) or a sense of recognition (trait correspondence). What is required most of all is a correspondence between long-term objectives and goals in life. Values are arguably the most relevant factor in longer relationships.

This study explores the viability of this line of reasoning in order to provide preliminary answers to the challenges brand managers and organisations face in their brand positioning efforts. In particular, this study asks the following question: When are values more important than traits and is this different for either products or services? We studied this at the level of brand category, unless explicitly stated otherwise. To this end, we conducted an experiment that tested whether the length of the relationship increases the importance of brand values over that of brand personality traits or functional characteristics when choosing products and services. First, we discuss the most important theory related to this question.

\section{2 | THE ROLE OF VALUES IN PURCHASING DECISIONS IN RELATION TO TIME}

When discussing the relative importance of different brand identity dimensions (functional attributes, personality traits, and values) in consumer choices, it is of course true that functional attributes are primary (i.e., "dissatisfiers"), because utilitarian need is considered to be the main driver for most product purchase intentions (Schuitema \& Groot, 2015). However, watches tell more than time. Brand traits ("is this watch like me?") and brand values ("how respectful is this brand towards the environment?") are involved by the way they connect to the intrinsic psychological needs of people (Vargo, Nagao, $\mathrm{He}$, \& Morgan, 2007). However, the question remains as to which of the two satisfiers (i.e., traits versus values) is more important, and which factors qualify this importance?
Values are very important trans-situational and cognitively expressed goals that guide people's attitudes as well as their behaviour in ways that are predictable (e.g., Allport, 1961; Bolzani, 2018; Feather, 1995; Hofstede, 1980; Maio, 2017; Rohan, 2000; Rokeach, 1973; Schwartz, 2012). The same applies to purchase intentions regarding products and services (Allen, 2002, 2006; Batra, Homer, \& Kahle, 2001; Doran, 2009; Vinson, Scott, \& Lamont, 1977). Alsem et al. (2007) and Zhang and Bloemer (2008) were the first to show that value congruency-whereby there is a match between a person's personal values and the perceived values of a brand-is an explanatory factor for behavioural effects. Voorn et al. (2016) subsequently showed that this may differ per type of product or service and that this mainly appears to be the case for durable products (e.g., cars and laptops) and services (e.g., banks and insurance companies) with which people have a relationship for a longer stretch of time.

However, it is as yet unclear which is most important: perceived values or perceived traits. The time factor could be of influence here because the greater the distance regarding decisions that involve time, the greater the psychological distance and level of abstractedness. For instance, focussing on a moment in time further away in the future increases the relevance and importance of higher level abstract construct features, such as values, in comparison with more concrete construct features such as functional product properties (Eyal, Sagristano, Trope, Liberman, \& Chaiken, 2009; Hernandez, Wright, \& Ferminiano Rodrigues, 2015; Lee \& Wang, 2017; Trope \& Liberman, 2010). A recent meta-analysis of 125 construal level studies confirmed the effects of psychological distance on abstractness (Soderberg, Callahan, Kochersberger, Amit, \& Ledgerwood, 2015). The ensuing construal levels showed a stable moderate curvilinear relationship, suggesting that higher level features become exponentially more important as distance through time increases. Moreover, although many construallevel studies adopt a binary view of construal levels (near moments versus far moments), Maglio and Trope (2018) suggest that distance can be placed along a continuous scale, as is the case in relationships.

In the current research, we assume that functional attributes will always be the most important characteristic of a product or service, regardless of the duration of the relationship that is involved (Gutman, 1982; Kotler \& Keller, 2012). However, we argue that traits, which are usually exhibited in immediately observed brand behaviour (Aaker, 1997; Freling, Crosno, \& Henard, 2011), become more important in shorter relationships in terms of identity ("Do I want to engage with a brand with these personality traits?"; Sirgy et al., 2016). Values, by contrast, which are by nature abstract higher level features, are the underlying drivers in long-term and abstract behaviour (Gecas, 1982; Hitlin, 2003; Maio, 2017: Schwartz, 2012) and are therefore more important as well as more predictive for longer relationships ("Do I want a longer relationship with this brand?"). This would mean that the importance of values increases in correspondence with the duration of the relationship. Thus,

H1a. Values are considered to be more important than traits in long retrospective or prospective relationships;

H1b. Traits are considered to be more important than values in shorter retrospective or prospective relationships. 
Incidentally, time appears to play a different role in retrospective or prospective decisions. For one thing, the future is unknown and based on intentions and more uncertainty. It is therefore more abstract in comparison with the past, which is based on certainties and facts (D'Argembeau \& Van der Linden, 2004). Having an impression of another's values therefore allows one to make predictions about attitudes and behavioural intentions (De Groot \& Steg, 2008), thereby reducing perceived risks and increasing trust (Zhang \& Bloemer, 2008). Finally, people are more emotionally engaged with the future than the past (Levine, Lench, Karnaze, \& Carlson, 2018; Van Boven \& Caruso, 2015). This is due to a devaluation of the emotional value of experiences in the past compared with the emotional value of expected experiences in the future (Caruso, Gilbert, \& Wilson, 2008). On the basis of these considerations, we propose that

H1c. Values will be even more important in long prospective relationships compared with values in long retrospective relationships.

However, the question remains whether the hypotheses posed here apply equally to both products and services. After all, services differ from products in numerous ways. In contrast to products, they are intangible, inseparable, variable, and perishable (Kotler \& Keller, 2012). It may also be difficult to assess services by their technical or utilitarian properties (Darby \& Karni, 1973; Galetzka, Verhoeven, \& Pruyn 2006; Mort \& Rose, 2004; Nelson, 1970, 1974; Zeithaml, 1981). Thus, because services bring along more risk and uncertainty, in so far as consumers lack tangible or concrete grounds for evaluation (Mitra, Reiss, \& Capella, 1999), consumers may primarily base their decisions on perceived brand values (Mort \& Rose, 2004; Voorn et al., 2016). After all, finding compatibility with one's own values can reduce the feeling of risk (Arts, Frambach, \& Bijmolt, 2011; Rogers, 2003; Zhang $\&$ Bloemer, 2008). That is why we propose that

$\mathrm{H} 2$. Values are considered more important than traits in consumer purchase decisions of services than of products.

In summary, this study examined the following hypotheses: (H1a) Values are considered to be more important than traits in long retrospective or prospective relationships, and traits are considered to be more important than values in shorter retrospective or prospective relationships; $(\mathrm{H} 1 \mathrm{~b})$ values will be even more important in long prospective relationships, compared with values in long retrospective relationships; and $(\mathrm{H} 1 \mathrm{c}$ and $\mathrm{H} 2)$ values are considered more important than traits in consumer purchase decisions of services than of products. We elaborate on the experiments in more detail below.

\section{3 | MATERIALS AND METHODS}

To facilitate the organisation of the experiments, two prestudies were organised.

\section{1 | Prestudy 1}

To organise the experiments, we first needed information on which categories of products and services are typically associated with usage for a couple of days, weeks, or years. To determine this, an online survey was conducted ( $N=300, M_{\text {age }}=48.9, S D=16.7 ; 47.7 \%$ female) to obtain national representative information through a panel provider based in the Netherlands. This resulted in a list of categories of products and services most often mentioned as being typically used for more than 2 years (cars and car insurance), a couple of months (shampoo and phone top-up cards), or a couple of days to weeks (soft drinks and travel agencies).

\section{2 | Prestudy 2}

A second online survey was organised to ascertain the top two most important functional attributes, brand personality traits and brand values. $N=300$ respondents $\left(M_{\text {age }}=49.8, S D=15.6 ; 51.3 \%\right.$ female $)$ from a Dutch online panel were randomly assigned to one of the six products or services that were obtained from the first survey: cars or car insurance, shampoo or phone top-up cards, soft drinks, or travel agencies. Respondents were asked to make a list of the functional attributes the product or service has to possess for them to be taken into consideration. They were subsequently asked to rank these attributes in order of importance on a 7-point Likert scale $(1=$ not important and 7 = very important).

This was followed by a request to score the importance (using the same Likert scale) of product personality traits (Govers \& Schoormans, 2005), whereby, in accordance with recommendations by Eisend and Stokburger-Sauer (2013), the 12-item brand personality traits scale ( $\alpha=0.86$ ) developed by Geuens, Weijters, and De Wulf (2009) was used (e.g., down to earth, stable, active, bold, simple, and sentimental). The same procedure was followed for product values (in line with Zhang \& Bloemer, 2008) whereby we used an adapted form of the 21-item Schwartz (2007) value scale ( $\alpha=0.93$;e.g., being creative, living in a safe and secure environment, being modest, and enjoying oneself). Both the product personality traits as well as the product values were randomised to prevent order effects.

This resulted in a list of the top two and bottom two functional attributes, product personality traits, and values for (each of the) the six products and services (See example for cars in Table 1).

The data obtained from the two prestudies were combined and subsequently used to set up the main study.

\section{I PARTICIPANTS, PROCEDURE, AND MATERIALS}

An online experiment was organised for which $N=175$ participants were recruited $\left(M_{\text {age }}=48.2, S D=19.2 ; 51 \%\right.$ female $)$ who were

TABLE 1 Overview of the top two and bottom two attributes, product personality traits and product values for cars

\begin{tabular}{llll}
\hline Car & Attributes & Traits & Values \\
\hline Top 2 & Safe & Responsibility & Security \\
\hline Top 2 & Economical & Activity & Hedonism \\
\hline Bottom 2 & Low tax & Simplicity & Stimulation \\
Bottom 2 & Sat Navigation & Emotionality & Power \\
\hline
\end{tabular}


TABLE 2 Overview of mean importance of functional attributes, traits, and values for products and services per time condition

\begin{tabular}{llllll} 
Product/services characteristics & $\mathbf{2}$ years ago & $\mathbf{2}$ months ago & Now & $\mathbf{2}$ months future & $\mathbf{2}$ years future \\
\hline Functional attributes & 5.7 & 5.7 & 5.9 & 5.7 & 6.3 \\
Traits & 4.1 & 4.0 & 4.3 & 4.2 & 4.3 \\
Values & 5.2 & 3.9 & 4.7 & 4.1 & 5.8
\end{tabular}

randomly assigned to one of the five time settings: 2 years in the past, 2 months in the past, now, 2 months in the future, or 2 years in the future.

For each of the five moments, participants responded to questions about a product and a service. For both the " 2 years in the past" and the " 2 years in the future" moments, the questions were about cars and car insurance. For the moments " 2 months in the past" and "2 months in the future," the questions involved shampoo and phone top-up cards. In the "now" moment, the product was a soft drink, and the service was a travel agency. For all moments, the participants were first asked which brand of product and service they used and then, as a manipulation check, they were asked how long they had already been using their current product or service. The average use of products and services confirmed our time span findings from prestudy 1: cars $M_{\text {useyears }}=6.7, S D=4.0$; car insurance $M_{\text {useyears }}=9.9$, $S D=11.7$; shampoo $M_{\text {useweeks }}=10.6, S D=8.6$; phone credit $M_{\text {useweeks }}=16.3, S D=15.1$; soft drink $M_{\text {usedays }}=4.0, S D=4.1$; and travel agency $M_{\text {usedays }}=11.0, S D=6.4$.

Subsequently, respondents were asked to imagine that they bought the relevant product or service in the time frame corresponding with the moment they were assigned to, that is, in the moments 2 years retrospectively or prospectively: "Now, here are some questions about the attributes that could be of importance to you when selecting a car. What was important to you when you bought your latest car? What attributes did you find very important, and which did you find less important? Imagine you bought your last car two years ago. Which attributes were important to you then? Please take a few moments to think about this. Press continue when you are ready." The same questions were formulated for the 2 months retrospectively or prospectively as well as the now moment. After this, respondents were asked to score 12 items in total-the randomised top two and bottom two attributes (four items), personality traits (four items), and values (four items) that were obtained during the second survey (see Table 1)-according to how important these were to them on a 7-point Likert scale (anchors: totally unimportant versus extremely important). The top two scoring attributes, traits, and values were subsequently used to analyse the results. All top two scores were in line with those found in prestudy 2 .

\section{5 | RESULTS}

Before we report on the outcomes in relation to the hypotheses that were formulated, we want to point out here that we first tested our general assumption that functional attributes are always considered to be the most important factor in making purchase decisions, regardless of the duration of the relationship with the products and services. In all five moments: 2 years ago, 2 months ago, now, 2 months in the future, and 2 years in the future, functional attributes were indeed considered to be most important compared with traits and values (all ps < 0.001; see Table 2).

Next, we investigated H1a: Values are considered to be more important than traits in long retrospective or prospective relationships.

A paired sample $t$ test was conducted to compare the difference in importance of values versus traits at a 2-year retrospective and prospective moment (see Figure 1).

Values were indeed considered to be more important than traits for making purchase decisions in both the "2 years ago" moment and the "2 years in the future" moment $\left(M_{\text {values }}=5.2, S D=1.0\right.$, and $\left.M_{\text {traits }}=4.1, S D=1.5\right), t(69)=7.12, p \leq 0.001, d=0.9,95 \%$ confidence interval $(\mathrm{Cl})[0.74,1.42]$ as well as in the 2 years in the future moment $\left(M_{\text {values }}=5.7, S D=0.84\right.$, and $\left.M_{\text {traits }}=4.3, S D=1.5\right), t(69)=6.98$, $p \leq 0.001, d=1.2,95 \% \mathrm{Cl}[0.91,1.91]$.

In addition, we performed extra simple regression analyses in order to ascertain the influence of the indicated number of days that respondents used the different products and services on the importance of values, in terms of both retrospective (from now till 2 years ago) and prospective (from now till 2 years in the future) relationships. The added benefit of a regression analyses is that it also addresses differences between participants for whom the time setting manipulation largely exceeds their current consumption habit and others for which the consumption habit is exceeding the time span. Retrospectively the increase in average days of use significantly predicted an increase in the importance of values, $M_{\text {valuesdaysuseretro }}=960, S D=2,257$, $\beta=0.27, t(208)=4.04, p<0.001,95 \% \mathrm{Cl}[0.0001,0.0003]$. The increase in average days of use also explained a significant proportion of variance in importance scores, $R^{2}=0.07, F(1,208)=16.33$, $p<0.001$. The same was the case prospectively $\left(M_{\text {valuesdaysusefuture }}=1,570, S D=5,188, \beta=0.26, t(208)=3.90\right.$, $p<0.001,95 \% \mathrm{Cl}[0.00004,0.0001]$. Also here, the increase in

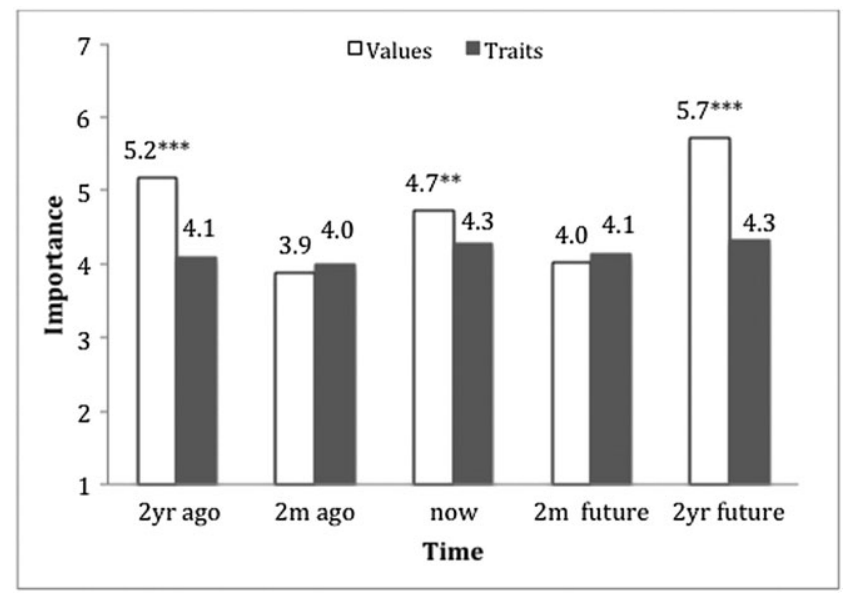

FIGURE 1 Difference in importance scores for traits and values per time moment. Note. ${ }^{*} p<0.05,{ }^{* *} p<0.01,{ }^{* * *} p<0.001$ 
TABLE 3 Outcome of a paired samples $t$ test to compare the importance of values and traits between services and products in all moments based on difference scores of values-minus-traits for services and products

\begin{tabular}{llllllll} 
Time & Mean & SD & $t$ & $d f$ & $p$ & $d$ & {$[95 \% \mathrm{CI}]$} \\
\hline 2 years ago & 1.14 & 1.72 & 3.94 & 1.34 & 0.000 & 0.85 & {$[0.553,1.732]$} \\
\hline 2 months ago & 0.75 & 1.61 & 2.79 & 1.35 & 0.009 & 0.56 & {$[0.206,1.309]$} \\
\hline Now & 0.16 & 1.78 & 0.522 & 1.36 & 0.605 & 0.13 & {$[0.455,769]$} \\
\hline 2 months future & 0.63 & 1.48 & 2.52 & 1.37 & 0.017 & 0.51 & {$[0.121,1.136]$} \\
\hline 2 years future & 0.90 & 1.39 & 3.84 & 1.38 & 0.001 & 0.58 & {$[0.424,1.377]$} \\
\hline
\end{tabular}

Note. $\mathrm{Cl}$ : confidence interval; SD: standard deviation.

average days of use explained a portion of the variance in importance scores, $R^{2}=0.07, F(1,208)=15.23, p<0.001$.

A comparable analysis of the influence of the number of days the respondents indicated using the different products and services on the importance of traits did, however, not produce any significant effects retrospectively, $M_{\text {traitsdaysuseretro }}=960, S D=2,257, \beta=0.06$, $t(208)=0.87, p<0.34,95 \% \mathrm{Cl}[0.00006,0.0002]$, nor prospectively, $M_{\text {traitsdaysusefuture }}=1,570, S D=5,188, \beta=0.04, t(208)=0.63$, $p<0.53,95 \% \mathrm{Cl}[0.00003,0.00005]$.

Overall, these outcomes confirm hypothesis $\mathrm{H} 1 \mathrm{a}$ and show a large effect for perceived values being considered more important than perceived personality traits with regard to purchasing decisions for products and services that have been or will be used for more than 2 years in the past or future, respectively. The increase of the importance of values versus traits was additionally confirmed by separate regression analyses.

Next, we turn to H1b:

Traits are considered to be more important than values in shorter retrospective or prospective relationships.

Traits are not considered to be more important than values at the retrospective 2-month moment $\left(M_{\text {traits }}=4.0, S D=1.8\right.$, and $\left.M_{\text {values }}=3.9, S D=1.8\right), t(69)=0.68, p \leq 0.5, d=0.06,95 \% \mathrm{Cl}$ $[-0.21,0.42]$, nor at the prospective 2-month moment $\left(M_{\text {traits }}=4.1\right.$, $S D=1.3$, and $\left.M_{\text {values }}=4.1, S D=1.4\right), t(69)=0.58, p \leq 0.6, d=0.07$, 95\% Cl [-0.21, 0.38].

H1c: Values will be even more important in long prospective relationships compared with values in long retrospective relationships.

An independent sample $t$ test was conducted to compare the difference in importance of (the average of product and service) values in the long prospective condition ( 2 years in the future moment) versus the long retrospective condition ( 2 years in the past). Values in the 2 years in the future moment were indeed considered more important for making purchase decisions than values in the 2 years ago moment $\left(M_{\text {values2yrsfuture }}=5.7, S D=0.84\right.$, and $\left.M_{\text {values2yrsago }}=5.2, S D=1.0\right)$, $t(69)=2.51, p<0.05, d=0.54,95 \% \mathrm{Cl}[0.11,0.99]$.

This outcome shows that values are considered to be more important in purchase decisions in long prospective relationships compared with long retrospective relationships. Thus, hypothesis $\mathrm{H} 1 \mathrm{c}$ is confirmed.
$\mathrm{H} 2$ : Values are considered more important than traits in consumer purchase decisions of services than of products.

A paired sample $t$ test was conducted to compare the difference in the importance of values versus traits between services and products based on values-minus-traits scores for services and products. In all moments, with the exception of the now moment, values were considered more important than traits in consumer purchase decisions of services than of products. Thus, in most of the consumer choice moments, values are considered to be more important than traits when choosing services compared with choosing products (see Table 3 for details). H2 is therefore largely supported.

\section{1 | Summary}

The results of our experiment show, as predicted, that perceived values are more important than perceived personality traits in longer relationships ( $\mathrm{H} 1 \mathrm{a})$ and that the importance of values increases (in comparison to traits) as the number of days that the products and services are used increases. Additionally, we found that traits are not considered to be more important than values in shorter retrospective or prospective relationships $(\mathrm{H} 1 \mathrm{~b})$. Our results further suggest that the importance of values is indeed stronger in the case of longer prospective relationships compared with longer retrospective relationships $(\mathrm{H} 1 \mathrm{c})$. Also, in most cases, perceived values are more important than traits for services than for products $(\mathrm{H} 2)$. We wish to point out, however, that the relatively small sample size that was used in our study may have exaggerated the effect sizes of some of our findings or may have obscured some other true effects in our analysis. Combined, these results show that the duration of a relationship influences the relative importance of values over traits in the consumer decision process, especially in prospective situations, and that this is particularly pertinent in the case of services compared with products.

\section{6 | DISCUSSION AND CONCLUSIONS}

Previous studies show that brand preference is influenced by the degree of congruence experienced between brand values and one's own values (Alsem et al., 2007; Zhang \& Bloemer, 2008). However, the extent to which this applies differs between products and services and also appears to be influenced by the duration of the relationship 
between brands and consumers (Voorn et al., 2016). These latter predictions were investigated in the current study.

The outcomes of our study confirm that of the various product or service categories, functional attributes, regardless of time, are the most important determinants in purchase decisions. This might be different, however, when consumers select between different categories of brands that are otherwise considered equal in terms of perceived functional attributes. In such cases, brand values might play a more important role than was found in the current, categorybased, study. More interestingly however, the results confirm the assumption that perceived values are more important than perceived personality traits in longer relationships and that this effect is stronger in prospective rather than retrospective relationships. Furthermore, we found support for the prediction that values are overall considered to be more important for services than for products and that this is influenced by the duration of the relationship. However, in shorter relationships, it seems, contrary to our prediction, that traits are not more important than values. Also, we found that the importance of traits versus values does not increase when the duration of the relationship increases, whereas the opposite is the case for values versus traits.

Our study therefore suggests that the duration of a relationship may be another way in which the length of time has been demonstrated to be of influence on the importance of values in the selection processes of products and services, as demonstrated in the construal level studies by Eyal et al. (2009) and Hernandez et al. (2015). These studies showed that the level of abstractness increases between making a decision now or in a moment in the future. This means the importance of values (versus attributes) increases with decisions involving the future. However, it is suggested (Maglio \& Trope, 2018) that this is not an exclusively binary process, whereby there are only two levels of construal in concrete near moments or abstract future moments. Rather, levels of abstraction can progress as the length of time increases, regardless of whether this happens retrospectively or prospectively. The current study shows that values, which are higher order abstract features, indeed become more important as the length of time increases, although this decision can start in a near moment. Although values become more important in future decisions, and therefore more abstract situations, they can be activated in more near situations as well by asking respondents to elaborate on future consequences of current decisions (Maio, 2017). This technique was used in this study by requesting the participants to consider the importance of functional attributes, traits, or values based on specific alternative relationship durations.

The current study also demonstrates that values are more important in decisions concerning the future than those involving the past. This confirms the theory in current literature that suggests that past experiences, which are known and therefore less abstract, are devalued in comparison with the more uncertain and thus more abstract decisions involving the future (Caruso et al., 2008; D'Argembeau \& Van der Linden, 2004; Van Boven \& Caruso, 2015). In such cases, knowing another's values offers a way to make predictions concerning their attitudes and behavioural intentions in the future, thereby reducing uncertainty and increasing trust. In the current study, this is particularly true for the importance of values for services.
The foregoing leaves very interesting questions open for future studies. One of these is which other determinants, besides the influence of time, exist that influence the importance of values for services? Services are higher in intangibility, inseparability, variability, and perishability compared with products (Kotler \& Keller, 2012), which makes services, in general, harder to evaluate on quality (Darby \& Karni, 1973; Galetzka et al., 2006; Nelson, 1970, 1974; Zeithaml, 1981). Might it be, for instance, the case that the intangibility of services also influences the importance of values as these, as suggested by Zhang and Bloemer (2008), are able to increase the level of trust if there is congruence between personal values with a brand's values?

Another possibility may be that in the case of longer relationships with a service (and especially credence services), perceived values become almost part of the dissatisfiers instead of making up part of the satisfiers (Vargo et al., 2007). Given the fact that, as psychological distance becomes greater, we have a tendency to fall back on even more abstract information when trying to gain a hold on reality (Rim, Uleman, \& Trope, 2009), it could be argued that values might play this role. This implies that a brand's functional attributes may play a more important role in selecting search services, and a brand's personality traits in the selection of experience services, as they help determine the desirability of interaction on the basis of congruity (Sirgy et al., 2016). Brand values may mostly play a part in assessing the (even more abstract) credence services, which, by their very nature, are almost impossible to evaluate in terms of quality compared with search and experience services (Sharma, Sivakumaran, \& Marshall, 2014). The distinction being, as defined by Darby and Karni (1973) and Nelson (1970), that one can judge the quality of search products and services before buying or using them, for example, a dress (Nelson, 1970) or jewellery and furniture (Zeithaml, 1981) and that the quality of experience products and services can only be determined after buying and using them, for example, a vacation or meals (Zeithaml, 1981). Compared with search and experience products and services, the quality of credence products and services is almost impossible to judge (by nonexperts), even after buying and using them, for example, vitamin pills, law office services (Darby \& Karni, 1973), or psychotherapy (lacobucci, 1992).

Additionally, information on values could possibly close the trust gap for services because their quality is almost impossible to judge based on functional attributes, as is possible in the case of products (Chernev \& Blair, 2015; MacMillan, Money, Money, \& Downing, 2005; Morgan \& Hunt, 1994). The predictive possibilities that insights into a brand's value offer, in terms of its intentions, might lead to an increase of the feeling of trust, which would lower the perceived higher risks in selecting credence services versus search and experience services (Mitra et al., 1999). Knowing the values that a brand demonstrates has many advantages. It has been observed in an experiment that brands that communicate their values enjoy more trust, a higher buying intention, better word of mouth intentions, and a higher evaluation of their quality compared with the same brands that do not communicate their values (Chernev \& Blair, 2015). Because it is impossible for nonexperts to evaluate credence services, even after buying and using them, communicating the brand's values may be of particular benefit to credence services. Further research into this seems useful. 
A limitation of our study is perhaps that, in our design, we have investigated the role of values in relation to products and services on a category level. This still leaves the question open as to how best to operationalise the concept of values on a brand level. At the brand level, there is direct communication with consumers who then gain better insight into the values that are important for a brand as well as their personality traits. But what is then the scope of freedom for product managers in selecting the values they would like to adopt for their brand? To what extent can these deviate from the values deemed important for the brand category? What are the degrees of freedom? Also, can values play a prominent role for brands for which values, at product and service category level, do not appear to be important in the selection process? A final limitation concerns the relatively small sample size. We acknowledge that this may have obscured effects or produced exaggerated effect sizes for observed effects. Clearly, these combined limitations call for follow-up research in which our findings are further substantiated.

\section{1 | Implications for practitioners}

Once again, it has become clear that the importance of values in consumers' choices can be more important than those of traits (Voorn et al., 2016). An additional outcome of our study is that the duration of the relationship appears to play an important part especially in decisions involving the future and that, in particular, services might particularly benefit from communicating relevant values to their consumers.

One question that remains for practitioners is the relevance for brands of different types of values. Traditionally, one of the fundamental principles in marketing has always been to align what a brand offers with what consumers find important. This also holds true for brand values (e.g., Aaker, 1991; Alsem et al., 2007; Gutman, 1982; Rokeach, 1973; Voorn et al., 2016; Zhang \& Bloemer, 2008). Increasingly, though brands seem to select issues relevant to society, they tend to find it more important to make their own value statements instead of selecting category values that consumers may find more important. For instance, Patagonia uses their own concern for the environment (which belongs to the value group of universalism, according to Schwartz, 2012) as the basis for its advertising campaigns (Carus, 2012). Dove, with their "Real Beauty" tagline, makes a statement against the "ideal woman" image often used in fashion, beauty, and the cosmetics industry, thereby advocating that all women should feel beautiful (Dove, 2016). And Heineken (2017) also recently opted to focus on values such as universalism and security in a world full of conflicts with their video commercial "Worlds Apart" (Sheehan Perkins, 2017). In this commercial, which received more than 11 million views on YouTube in 3 weeks, different people who are opposites of each other (in sexual orientation, political views, or otherwise) end up in a relationship by daring to open up to each other (in line with the brand's international slogan "Open Your World"), thereby making the world a better place.

However, there is controversy in professional circles about the effectiveness of using relevant societal values in marketing campaigns, which is also a central point of discussion in "purpose marketing" (Ritson, 2017). For instance, are brands that are engaged in purpose marketing really more successful in stimulating sales compared with more "traditional" brands focusing on functional and brand personality traits (e.g., Aaker, 1997; Aguirre-Rodriguez et al., 2012; Sirgy et al., 1991; Sirgy et al., 2016)?

The current discussion on the effectiveness of purpose marketing highlights a distinction between brands using values that are category driven (such as in this study), or society driven, such as concern for the environment (Patagonia), self-respect (Dove), and making the world a little bit more peaceful (Heineken). These latter values are linked with issues that will remain important in the long run. And, as we have shown, as the importance of values increases under the influence of (relationship) time, it may be of interest to the field of marketing to investigate the benefits of using societal values rather than (classic) category-driven values. What would happen, for example, if consumers are offered the choice between a bar of chocolate that offers the quality assurance of a centuries old artisanal production method, versus a bar of chocolate that ensures that no child labour has been used in its production, such as the very popular Dutch brand Tony Chocolonely? Both brands use expressions of values, but how is this perceived among consumers? Construal level theory possibly offers a few leads in finding a satisfying answer to this question because it suggests that certain functional attributes (values that are more related to product quality) especially play a role in the present (e.g., Hernandez et al., 2015; Liberman \& Trope, 1998; Trope, Liberman, \& Wakslak, 2007), whereas more abstract constructs (such as societal values like the fight against child labour) particularly play a part in the future (Eyal et al., 2009).

It certainly seems that marketing managers would be wise to study which values are relevant for their brands, as seen from the perspective of consumers, as this may help in reaching the desired brand outcomes. Whether they should focus on values that are more product-related or more abstract and "societally relevant" remains open for debate, for now.

In summary, our study supplements previous research on the importance of perceived product and service category values, versus functional attributes and traits in the consumer selection process. Our study shows that values are considered more important than traits in the case of longer retrospective and prospective product relationships. This is particularly true in the case of services. Other drivers, such as the role of values in relation to the psychological distance that is experienced towards search, experience, and credence products and services, as well as the effectiveness of different value types, need to be investigated further especially at brand level.

\section{ORCID}

Ronald J.J. Voorn (1) http://orcid.org/0000-0002-7112-580X

\section{REFERENCES}

Aaker, D. A. (1991). Managing brand equity. New York: Free Press.

Aaker, J. L. (1997). Dimensions of brand personality. Journal of Marketing Research, 347-356.

Aguirre-Rodriguez, A., Bosnjak, M., \& Sirgy, M. J. (2012). Moderators of the self-congruity effect on consumer decision-making: A meta-analysis. Journal of Business Research, 65(8), 1179-1188.

Allen, M. W. (2002). Human values and product symbolism: Do consumers form product preference by comparing the human values symbolized by a product to the human values that they endorse? Journal of Applied Social Psychology, 32(12), 2475-2501. 
Allen, M. W. (2006). A dual-process model of the influence of human values on consumer choice. Revista Psicologia: Organizações e Trabalho, 6, 15-49.

Allport, G. W. (1961). Pattern and growth in personality. New York: Holt, Rinehart \& Winston.

Alsem, K. J., Wieringa, J., \& Hendriks, M. (2007). The relation between values-based self-congruity and brand loyalty. In Proceedings of the 36th EMAC Conference. Reykjavik: European Marketing Academy.

Amos, E. A., \& Weathington, B. L. (2008). An analysis of the relation between employee-Organization value congruence and employee attitudes. The Journal of Psychology, 142(6), 615-632.

Arts, J. W., Frambach, R. T., \& Bijmolt, T. H. (2011). Generalizations on consumer innovation adoption: A meta-analysis on drivers of intention and behavior. International Journal of Research in Marketing, 28(2), 134-144.

Batra, R., Homer, P. M., \& Kahle, L. R. (2001). Values, susceptibility to normative influence, and attribute importance weights: A nomological analysis. Journal of Consumer Psychology, 11(2), 115-128.

Belk, R. W. (1988). Possessions and the extended self. Journal of Consumer Research, 15(2), 139-168.

Bolzani, D. (2018). Personal values and characteristics of remittance channels: Insights from a means-end-chain study. Journal of Consumer Behaviour, 17(1), e140-e152.

Carus, F. (2012, July 17). Patagonia: A values-led business from the start. Retrieved May 12, 2017, from https://www.theguardian.com/sustainable-business/patagonia-values-led-business-benefit-corp.

Caruso, E. M., Gilbert, D. T., \& Wilson, T. D. (2008). A wrinkle in time: Asymmetric valuation of past and future events. Psychological Science, 19(8), 796-801.

Chernev, A., \& Blair, S. (2015). Doing well by doing good: The benevolent halo of corporate social responsibility. Journal of Consumer Research, 41(6), 1412-1425.

Darby, M. R., \& Karni, E. (1973). Free competition and the optimal amount of fraud. The Journal of Law and Economics, 16(1), 67-88.

D'Argembeau, A., \& Van der Linden, M. (2004). Phenomenal characteristics associated with projecting oneself back into the past and forward into the future: Influence of valence and temporal distance. Consciousness and Cognition, 13(4), 844-858.

De Chernatony, L. (2009). Towards the holy grail of defining 'brand. Marketing Theory, 9(1), 101-105.

De Groot, J. I., \& Steg, L. (2008). Value orientations to explain beliefs related to environmental significant behavior: How to measure egoistic, altruistic, and biospheric value orientations. Environment and Behavior, 40(3), 330-354.

Doran, C. J. (2009). The role of personal values in fair trade consumption. Journal of Business Ethics, 84(4), 549-563.

Dove (2016, June 22). Our Vision. Retrieved May 12, 2017, from https:// www.dove.com/us/en/stories/about-dove/our-vision.html.

Eisend, M., \& Stokburger-Sauer, N. E. (2013). Measurement characteristics of Aaker's brand personality dimensions: Lessons to be learned from human personality research. Psychology and Marketing, 30(11), 950-958.

Eyal, T., Sagristano, M. D., Trope, Y., Liberman, N., \& Chaiken, S. (2009). When values matter: Expressing values in behavioral intentions for the near vs. distant future. Journal of Experimental Social Psychology, 45(1), 35-43.

Feather, N. T. (1995). Values, valences, and choice: The influences of values on the perceived attractiveness and choice of alternatives. Journal of Personality and Social Psychology, 68(6), 1135.

Freling, T. H., Crosno, J. L., \& Henard, D. H. (2011). Brand personality appeal: conceptualization and empirical validation. Journal of the Academy of Marketing Science, 39(3), 392-406.

Friedman, U. (2015, February 13). How an ad campaign invented the diamond engagement ring. The Atlantic, Retrieved September 22, 2017 from goo.gl/qCMRJv.
Galetzka, M., Verhoeven, J. W., \& Pruyn, A. T. H. (2006). Service validity and service reliability of search, experience and credence services: A scenario study. International Journal of Service Industry Management, 17(3), 271-283.

Gawronski, B., Bodenhausen, G. V., \& Becker, A. P. (2007). I like it, because I like myself: Associative self-anchoring and post-decisional change of implicit evaluations. Journal of Experimental Social Psychology, 43(2), 221-232.

Gecas, V. (1982). The self-concept. Annual Review of Sociology, 8(1), 1-33.

Geuens, M., Weijters, B., \& De Wulf, K. (2009). A new measure of brand personality. International Journal of Research in Marketing, 26(2), 97-107.

Govers, P. C., \& Schoormans, J. P. (2005). Product personality and its influence on consumer preference. Journal of Consumer Marketing, 22(4), 189-197.

Gutman, J. (1982). A means-end chain model based on consumer categorization processes. Journal of Marketing, 46(2), 60-72.

Hayman, B. (2017). The 2017 brand purpose leaders, plus key trends for 2018. Retrieved from https://goo.gl/a83mXV

Heineken (2017,April 20). Worlds apart [Video File]. Retrieved from https://youtu.be/8wYXw4K0A3g

Hernandez, J. M. D. C., Wright, S. A., \& Ferminiano Rodrigues, F. (2015). Attributes versus benefits: The role of construal levels and appeal type on the persuasiveness of marketing messages. Journal of Advertising, 44(3), 243-253.

Hitlin, S. (2003). Values as the core of personal identity: Drawing links between two theories of self. Social Psychology Quarterly, 66(2), 118-137.

Hofstede, G. (1980). Motivation, leadership, and organization: Do American theories apply abroad? Organizational Dynamics, 9, 42-63.

lacobucci, D. (1992). An empirical examination of some basic tenets of services. In T. A. Swartz, D. E. Bowen, \& S. W. Brown (Eds.), Advances in services marketing and management (pp. 23-52). Greenwich, CT: JAI.

Jonsen, K., Galunic, C., Weeks, J., \& Braga, T. (2015). Evaluating espoused values: Does articulating values pay off? European Management Journal, 33(5), 332-340.

Kotler, P., \& Keller, L. K. (2012). Marketing Management. Harlow: Pearson Education.

Lee CT., Wang MY. (2017). Appeals of product pictures on the product detail page: The effect of mental imagery. In: Kurosu M., (eds). Human-computer interaction. User interface design, development and multimodality. $\mathrm{HCl}$ 2017. Lecture notes in computer science, Vol 10271 Springer, Cham

Levine, L. J., Lench, H. C., Karnaze, M. M., \& Carlson, S. J. (2018). Bias in predicted and remembered emotion. Current Opinion in Behavioral Sciences, 19, 73-77.

Liberman, N., \& Trope, Y. (1998). The role of feasibility and desirability considerations in near and distant future decisions: A test of temporal construal theory. Journal of Personality and Social Psychology, 75(1), 5-18.

MacMillan, K., Money, K., Money, A., \& Downing, S. (2005). Relationship marketing in the not-for-profit sector: An extension and application of the commitment-trust theory. Journal of Business Research, 58(6), 806-818.

Maglio, S. J., \& Trope, Y. (2018). Temporal orientation. Current Opinion in Psychology. In press, https://doi.org/10.1016/j.copsyc.2018.05.006

Maio, G. R. (2017). The psychology of human values. In Psychology press. New York: Routledge.

Mitra, K., Reiss, M. C., \& Capella, L. M. (1999). An examination of perceived risk, information search and behavioral intentions in search, experience and credence services. Journal of Services Marketing, 13(3), 208-228.

Morgan, R. M., \& Hunt, S. D. (1994). The commitment-trust theory of relationship marketing. The Journal of Marketing, 58(3), 20-38. 
Mort, G. S., \& Rose, T. (2004). The effect of product type on value linkages in the means-end chain: implications for theory and method. Journal of Consumer Behaviour, 3(3), 221-234.

Naas, R. (2016, December 9). Patek Philippe celebrates 20 years of its iconic advertising campaign. Forbes. Retrieved on September 22, 2017 from https://goo.gl/GytkBb.

Nelson, P. (1970). Information and consumer behavior. Journal of Political Economy, 78(2), 311-329.

Nelson, P. (1974). Advertising as information. Journal of Political Economy, 82(4), 729-754.

Nolthe and Lauf Bank (2017). A bank for life. Retrieved on September 17, 2017 from https://www.nolteundlauth.de/projects/a-bank-for-life.

Rim, S., Uleman, J. S., \& Trope, Y. (2009). Spontaneous trait inference and construal level theory: Psychological distance increases non-conscious trait thinking. Journal of Experimental Social Psychology, 45(5), 1088-1097.

Ritson, M. (2017, May 10). Heineken should remember marketing is about profit, not purpose. Retrieved May 12, 2017, from https://www. marketingweek.com/2017/05/10/heineken-marketing-purposeprofit/.

Rodrigues Vila, O. \& Bharadwaj, S. (2017). Competing on social purpose. Harvard Business Review September-October, 94-101.

Rogers, E. M. (2003). Diffusion of innovations (5th ed.). New York, NY: The Free Press.

Rohan, M. J. (2000). A rose by any name? The values construct. Personality and Social Psychology Review, 4(3), 255-277.

Rokeach, M. (1973). The nature of human values. New York: Free press.

Schuitema, G., \& Groot, J. I. (2015). Green consumerism: The influence of product attributes and values on purchasing intentions. Journal of Consumer Behaviour, 14(1), 57-69.

Schwartz, S.H. (2007). A proposal for measuring value orientations across nations. A methodology proposal for the European Social Survey organization. Via https://goo.gl/6CidLD.

Schwartz, S. H. (2012). An overview of the Schwartz theory of basic values. Online Readings in Psychology and Culture, 2(1), 11.

Sharma, P., Sivakumaran, B., \& Marshall, R. (2014). Exploring impulse buying in services: Toward an integrative framework. Journal of the Academy of Marketing Science, 42(2), 154-170.

Sheehan Perkins, M. (2017, April 28). A Heineken commercial puts Pepsi's "protest" ad to shame. Retrieved May 12, 2017, from https://goo.gl/ $\mathrm{VfDH} 1 \mathrm{Z}$.

Sirgy, M. J., Johar, J. S., Samli, A. C., \& Claiborne, C. B. (1991). Self-congruity versus functional congruity: Predictors of consumer behavior. Journal of the Academy of Marketing Science, 19(4), 363-375.

Sirgy, M. J., Lee, D., \& Grace, B. Y. (2016). Revisiting self-congruity theory in consumer behaviour. In Routledge international handbook of consumer psychology (pp. 185-201). New York, NY: Routledge.

Soderberg, C. K., Callahan, S. P., Kochersberger, A. O., Amit, E., \& Ledgerwood, A. (2015). The effects of psychological distance on abstraction: Two meta-analyses. Psychological Bulletin, 141(3), 525.

Strahilevitz, M. A., \& Loewenstein, G. (1998). The effect of ownership history on the valuation of objects. Journal of Consumer Research, 25(3), 276-289.

Trope, Y., \& Liberman, N. (2010). Construal-level theory of psychological distance. Psychological Review, 117, 440-463.

Trope, Y., Liberman, N., \& Wakslak, C. (2007). Construal levels and psychological distance: Effects on representation, prediction, evaluation, and behavior. Journal of Consumer Psychology, 17(2), 83-95.

Van Boven, L., \& Caruso, E. M. (2015). The tripartite foundations of temporal psychological distance: Metaphors, ecology, and teleology. Social and Personality Psychology Compass, 9(11), 593-605.

Vargo, S. L., Nagao, K., He, Y., \& Morgan, F. W. (2007). Satisfiers, dissatisfiers, criticals, and neutrals: A review of their relative effects on customer (dis) satisfaction. Academy of Marketing Science Review, 11(2), 1-19.

Vinson, D. E., Scott, J. E., \& Lamont, L. M. (1977). The role of personal values in marketing and consumer behavior. Journal of Marketing, 41(2), 44-50.

Voorn, R. J. J., van der Veen, G., van Rompay, T. J. L., Hegner, S. M., \& Pruyn, A. T. H. (2016). The role of values in the consumer brand selection process. In 45th EMAC Annual Conference, Marketing in the age of data (EMAC2016), Oslo, Norway, May 24-27, 2016 (p. 153). European Marketing Academy. EMAC.

Wang, W., Fu, Y., Qiu, H., Moore, J. H., \& Wang, Z. (2017). Corporate social responsibility and employee outcomes: A moderated mediation model of organizational identification and moral identity. Frontiers in Psychology, 8, Article 1906, 1-14.

Ye, Y., \& Gawronski, B. (2016). When possessions become part of the self: Ownership and implicit self-object linking. Journal of Experimental Social Psychology, 64, 72-87.

Zeithaml, V. L. (1981). How consumer evaluation processes differ between goods and services. In J. H. Donnelly, \& W. R. George (Eds.), Marketing of Services (pp. 186-190). Chicago: American Marketing Association.

Zhang, J., \& Bloemer, J. M. (2008). The impact of value congruence on consumer-service brand relationships. Journal of Service Research, 11(2), 161-178.

Ronald Voorn, MSc EMP, is a former global CMO and international general manager for the Heineken company. He switched careers in 2011 and obtained his master's degree in marketing communication in 2013 at the University of Twente. Currently, he works as a senior lecturer in consumer behaviour at the Utrecht University of Applied Sciences and consumer psychology at the University of Twente. As a PhD student, he is researching the role that human values play in consumer decisions on brands.

Dr. Gerrita van der Veen has spent her life working as a social psychologist, having graduated and been awarded a doctorate at VU University Amsterdam. She has over 20 years of experience in (marketing) research and specialises in consumer behaviour in relation to brand strategy, concept development, and product innovation. In addition to her work for the Utrecht University of Applied Sciences as a professor in Marketing, Market Research, and Innovation, as well as managing director of the Research Centre for Innovation and Business, she also works as a partner at HIGHValue in Amsterdam.

Dr. Thomas van Rompay is an Associate Professor at the Department of Communication Science of the University of Twente in the Netherlands. He has a background in cognitive psychology. After obtaining his master's degree at Leiden University, he pursued his PhD at Delft Technical University, Department of Industrial Design Engineering. Specifically, he studied design experience from an embodied cognition perspective, investigating how design communicates meaning and affect. Since 2005, he works at The University of Twente. His current research projects take place on the threshold of design and psychology where he studies, amongst others, influences of environmental design and technology on health and well-being, and multisensory experiences as a function of packaging design. 
Prof. Dr. Ad Pruyn obtained his PhD in (experimental and social) psychology at the University of Groningen (the Netherlands) in 1986. He pursued his career at the Rotterdam School of Management (Erasmus University) where he worked as an Associate Professor of Consumer Behaviour for 15 years. He is currently employed as a Professor of Marketing Communication and Consumer Behaviour at the Faculty of Behavioural Sciences, University of Twente (the Netherlands). Areas of interest include time and consumer behaviour, the dynamics of social influence, and relationship management in the service industry. He has worked as guest professor/visiting scholar at the Shanghai University of Technology (People's Republic of China), the University of
California in Los Angeles (USA), Universitas Indonesia (Jakarta), ESADE Barcelona (Spain), Warsaw School of Economics (Poland), and the University of Innsbruck (Austria).

How to cite this article: Voorn RJJ, van der Veen G, van Rompay TJL, Pruyn ATH. It takes time to tango: The relative importance of values versus traits in consumer brand relationships. J Consumer Behav. 2018;17:532-541. https://doi.org/ 10.1002/cb.1737 